\title{
COMMUNITY RESPONSE TO THE IMPLEMENTATION OF THE ACCELERATION PROGRAM OF FOOD CONSUMPTION DIVERSIFICATION IN CENTRAL SULAWESI
}

\author{
Muhardi \\ Department of Agrotechnology, Agriculture Faculty of Tadulako University, Palu, Indonesia
}

https://doi.org/10.35410/IJAEB.2020.5572

\begin{abstract}
This research aimed to determine the community response to the implementation of the acceleration program of food consumption diversification in Central Sulawesi. The research was done by survey, conducted in all regencies that were targeted by activities and received funding from the center, namely: Donggala Regency, Parigi Moutong Regency, Poso Regency, Toli-Toli Regency, and Banggai Regency. In each regency, sampling (respondent) was done by simple random sampling for each target group of participants, as many as 30 people each regency. Retrieval of respondent data with interview techniques used a questionnaire instrument that had been prepared previously. The results showed that more than $70 \%$ of the respondents had an area of arable land above 1.0 ha and an average yardland area of $1,384.5 \mathrm{~m} 2$. The types of crops cultivated in yardland vary considerably between food, fruit, vegetables, and medicinal crops. The food ingredients usually consumed apart from rice were corn, tubers, and bananas; however, households were not yet able to replace rice as the staple food.
\end{abstract}

Keywords: Rice, corn, tubers, bananas, food ingredients.

\section{INTRODUCTION}

Law Number 7 of 1996 requires that food security is the responsibility of the government together with the community, and food diversification is an effort to increase food security. At the beginning of the '60s, the need for diversification of food began to be realized. The government has begun to encourage the consumption of staple foods other than rice, but this policy was only a reaction to the food crisis, and consumption by the community, especially the lower class, was carried out because of necessity. Food diversification basically includes aspects of production, consumption, marketing, and distribution [1-3]. The government has explicitly launched a food diversification policy through Presidential Instruction No. 14 of 1974 concerning the Improvement of People's Food Menu. After running for more than three decades, the impact of food diversification in its development was considered not to have shown satisfactory results, especially in increasing the awareness of the people who were still weak. Since 2006, the Food Security Council conference agreed to do an acceleration program of food consumption diversification [4], which aimed to further accelerate the achievement of diverse, nutritionally balanced, and safe food consumption [5].

The movement of the acceleration program of food consumption diversification has recently received serious attention from the President of the Republic of Indonesia, marked by the 
Vol. 5, No. 06; 2020

ISSN: $2456-8643$

issuance of Presidential Regulation No. 22 of 2009 concerning the Policy of Acceleration of Food Consumption Diversification Based on Local Resources. The presidential regulation included the target of acceleration of food consumption diversification, namely the achievement of a diverse, nutritionally balanced, and safe food consumption pattern which was reflected in the achievement of the national average of Expected Food Pattern score of 95.0 in 2015 [5].

The operational steps of the presidential regulation are contained in the Regulation of the Minister of Agriculture Number 43 / Permentan / OT.140 / 10/2009 concerning the Movement for the Acceleration of Food Consumption Diversification Based on Local Resources. This Regulation of the Minister of Agriculture is a reference for all regions in the context of its implementation in the field. A more specific description for the area of Central Sulawesi Province has also been outlined in the Central Sulawesi Governor Regulation Number 15 of 2010 concerning the Movement for the Acceleration of Food Consumption Diversification Based on Local Resources. The aim of this movement was to encourage the acceleration of food consumption diversification and nutrition in the community through: (1) increasing the knowledge, understanding, awareness, and skills of the community in the development of diverse, nutritionally balanced, and safe food consumption patterns based on local resources, and (2) encouraging the growth of a food industry based on local raw ingredients to support the acceleration of food consumption diversification and nutrition. The targets of the movement's activities were the realization of a diverse, nutritionally balanced, and safe food consumption pattern which was reflected in the achievement of an average of Expected Food Pattern score for Central Sulawesi province of at least 84 in 2009 and close to 95 in 2015 [6].

There were many measures used in evaluating the achievement of food diversification, one of which was the Expected Food Pattern score introduced by FAO-RAPA in 1989 [7]. The Expected Food Pattern is defined as the composition of the food group that can be consumed to meet energy needs and provide all nutrients in sufficient quantities. The diversification program is considered successful if it has reached the Expected Food Pattern score of 100 [4]. In other words, if the Expected Food Pattern score gets closer to 100, the community's food consumption will be more diverse, or the acceleration program of food consumption diversification can be considered successful. If you look at the Expected Food Pattern score at the national level, the 2009 to 2011 period fluctuated from 75.7 in 2009, increased to 77.5 in 2010, then fell again in 2011 to 77.3, and in 2012, Expected Food Pattern even tended to decrease again. This was due to the low consumption of animal products and vegetables and fruits. Even the consumption of the grains group was still very large with a proportion of 61.8 percent [8]. Likewise, the Expected Food Pattern score data for the Central Sulawesi region, which was still around 80, showed that there were still many problems and obstacles in the field, especially in implementing the acceleration program of food consumption diversification.

One of the main activities in the acceleration program of food consumption diversification was the empowerment of women's groups by optimizing the yard and providing food and nutrition extension. Although this activity has been done in three fiscal years (2009, 2010, and 2011) through relevant agencies at both the regency/city level and Central Sulawesi Province, the expected food pattern value from 2013 to 2018 was still fluctuating and the value was as follows: $81.9 ; 81.1 ; 86.4 ; 82.2 ; 89.4$ and 78.9 [9]. This shows that the program has not been fully 
implemented by the community, especially the target groups. This research aimed to determine the community response to the acceleration of food consumption diversification in Central Sulawesi.

\section{MATERIALS AND METHODS}

The research was carried out by a survey conducted in all regencies that were targeted by activities and received funding from the center, namely: Donggala Regency, Parigi Moutong Regency, Poso Regency, Toli-Toli Regency, and Banggai Regency. Materials and equipment used in this survey included writing tools, voice recording devices and pictures, and was assisted by the use of a questionnaire.

In each regency, sampling (respondent) was done by simple random sampling for each target group of participants. The population in this research comprised all members of the target group of participants, namely the women who were members of the dasawisma group and the women farmers group who were recorded as beneficiary groups by the manager of the acceleration program of food consumption diversification in each regency. The numbers of respondents sampled were 30 people in each regency. Retrieval of respondent data with interview techniques used a questionnaire instrument that had been prepared previously.

All data were collected by observation and interviews of target group participants. Additionally, interviews were also done with other parties such as village officials, field extension labors, and technical teams from related agencies. Field survey data results were analyzed using quantitative descriptive analysis, namely an analysis that describes the condition of data and information within the scope of the area which is strengthened by information from related agencies and from various parties so that it can provide description representatively and accurately for each regency and produce as objective a description as possible.

\section{RESULTS AND DISCUSSION}

\subsection{Characteristics of Respondents}

The characteristics of the respondents recorded included age, latest education, main job, and the number of family members (Table 1).

Table 1. Characteristics of respondents

\begin{tabular}{|l|c|c|c|c|c|}
\hline \multirow{2}{*}{\multicolumn{2}{|c|}{ Characteristics }} & \multicolumn{5}{c|}{ Regencies } \\
\cline { 2 - 6 } & Donggala & Parimo & Poso & Tolitoli & Banggai \\
\hline Age (years) & $24-62$ & $22-61$ & $21-58$ & $27-52$ & $22-56$ \\
\hline Education: & & & & & \\
\hline Elementary school (\%) & 17.42 & 15.41 & 16.57 & 21.32 & 19.31 \\
\hline Junior High School (\%) & 36.36 & 38.52 & 39.22 & 42.77 & 41.75 \\
\hline
\end{tabular}


International Journal of Agriculture, Environment and Bioresearch

Vol. 5, No. 06; 2020

ISSN: $2456-8643$

\begin{tabular}{|l|c|c|c|c|c|}
\hline Senior High School (\%) & 41.40 & 42.38 & 41.00 & 34.28 & 36.84 \\
\hline College Student (\%) & 4.82 & 3.69 & 3.21 & 1.63 & 2.1 \\
\hline Job: & & & & & \\
\hline Civil servants (\%) & 7.52 & 6.37 & 8.10 & 5.90 & 5.79 \\
\hline Farmers (\%) & 39.10 & 43.37 & 46.12 & 51.11 & 53.48 \\
\hline Self-employed (\%) & 53.38 & 50.26 & 45.78 & 42.99 & 40.73 \\
\hline Number of family members (soul) & $1-5$ & $2-5$ & $1-4$ & $2-7$ & $1-9$ \\
\hline
\end{tabular}

Table 1 shows the average age of the respondent as still productive, which implied that the respondent was still active in carrying out daily activities, especially in making a living. The education level of the respondents varied greatly from elementary school to undergraduate level, but the dominant education levels of respondents were junior high school and senior high school. Broadly speaking, the main job of the respondents consists of only three types, namely civil servants, farmers, self-employed, but generally, they are farmers and self-employed. The number of family members varies from 1 to 9 people with an average of 4 people; if it is disaggregated based on the number of family members, the small family is 4 people consisting of 2 parents and 2 children, and the large family is more than four people in the household.

\subsection{Ownership of Resources}

\section{Arable land}

Ownership of the respondent arable land was quite varied in terms of the area and the types of crops cultivated on it. Based on the recapitulation of arable land area data outside the yardland of the respondent, it was known that their arable land area ranges from 0 to 5 ha. In other words, there were a number of respondents who did not have arable land other than their yards. The variation of the arable land area based on a certain wide range is shown in Figure 1.

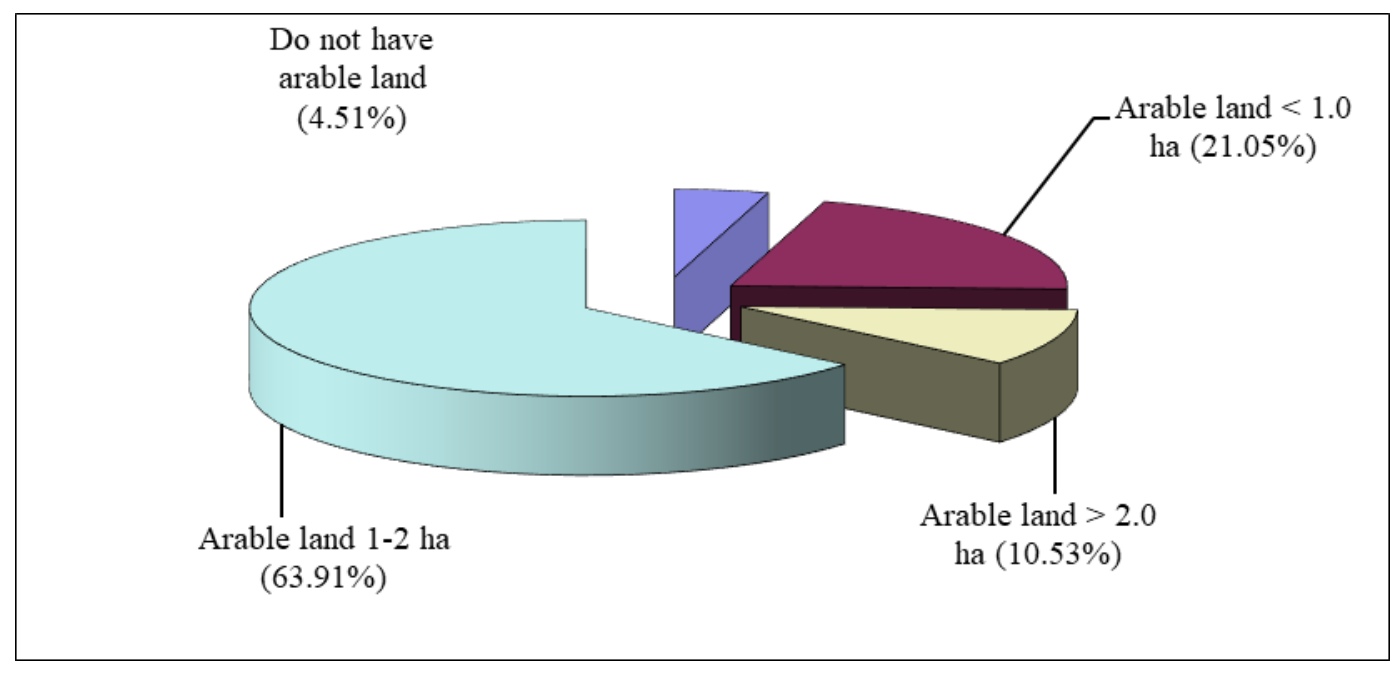


Figure 1. Distribution percentage of the arable land ownership of respondent

Figure 1 shows that, generally, the respondents had an arable land area of 1 to 2 ha (63.91\%). In terms of the aspect of commodities types cultivated on arable land, quite varied data were obtained which were generally categorized as 3 groups, namely: food crops, horticultural crops, and plantation crops. The types of food crops cultivated by the respondents consisted of rice, corn / secondary crops, tubers, and bananas, while the sago crop, which was also popular, grows naturally and has not been cultivated. The types of horticultural crops cultivated on arable land were fruit crops (such as bananas, mangoes, jackfruit, papaya, guava, and so on), vegetables, spices, and medicines, grown both individually and in mixed crops. The types of plantation crops that were mostly cultivated by the respondents alone were cocoa, followed by a combination of coconut and cocoa as well as single coconut trees, which were respectively cultivated by respondents as much as $46.43 \% ; 18.75 \%$, and $14.29 \%$. The rest were cloves, nutmeg, candlenut, and cashews which were generally combined with coconut, cocoa, or clove crops.

\section{Yardland}

The yardland area of the respondents varied between 12 to $10,000 \mathrm{~m}^{2}$, with an average area of $1,343.8 \mathrm{~m}^{2}$ (Table 2).

Table 2. The range and average area of yardland $\left(\mathrm{m}^{2}\right)$

\begin{tabular}{|l|c|c|c|c|c|}
\hline \multirow{2}{*}{ Characteristics } & \multicolumn{5}{|c|}{ Regencies } \\
\cline { 2 - 6 } & Donggala & Parimo & Poso & Tolitoli & Banggai \\
\hline range & $200-10,000$ & $150-7,500$ & $100-6,000$ & $24-5,000$ & $12-8,000$ \\
\hline average & 1,498 & 1,321 & 1,179 & 1,110 & 1,610 \\
\hline
\end{tabular}

Most of the land area below $500 \mathrm{~m}^{2}$ was owned by $39.85 \%$ of the respondents, the land area above $1,000 \mathrm{~m}^{2}$ was owned by around $36.09 \%$ of the respondents, and the remaining, which was $500-1,000 \mathrm{~m}^{2}$, was owned by $24.06 \%$ of the respondents. Respondents have used their yardland as a source of food and income with quite a variety of commodities. Commodities cultivated in the yard were food crops, horticulture, and livestock. Types of food crops were cassava, sweet potato, banana, and peanut. Types of crops from the horticultural group included banana, mango, jackfruit, papaya, and so on, while the types of vegetables cultivated in the yardland included tomatoes, chilies, long beans, eggplant, spinach, kale, and so on. In addition, there were also respondents who cultivated medicinal plants (physic garden) such as ginger, galangal, green chiretta, turmeric, and other rhizome-producing plants. The livestock kept in the yardland were chickens and goats.

The agricultural products cultivated by the respondents in order to meet household consumption were quite varied in proportion. However, most $(39.85 \%)$ stated that they could only fulfill part of their total consumption needs (less fulfilled $\leq 50 \%$ of total consumption), and around $33.83 \%$ 
stated that they almost fulfilled their consumption needs; only a few managed to have crops to be sold. Farming was able to meet household direct consumption needs between $10-80 \%$ or an average of about $47 \%$. The survey results show that the largest role of farming in contributing to meeting household consumption needs was in Tolitoli Regency because almost half of the respondents stated that their household consumption had been fulfilled from their own farming products, and $38.15 \%$ of respondents stated that their consumption needs were almost fulfilled. This research is relevant to the findings of Alam [10] which shows that members of the group of women farmers and dasawisma have consumed various types of vegetables that they got from the use yield of household yards, so that diverse food patterns can be realized. The more diverse the pattern of household food consumption, the more food diversification would be created.

\subsection{Prospects of Behavior Change}

This survey also includes opportunities for changes in respondent behavior that could encourage the achievement of goals of the acceleration program of food consumption diversification. Assessment of the prospects of changes in respondent behavior after participating in activities in the acceleration program of food consumption diversification, including staple foods, types of staple food substitutes, the intensity of food consumption other than rice, was made from the responses to the position of rice as staple food and foods deemed more appropriate to replace rice, and statements about whether or not to change rice with other foods as staple foods.

The types of food usually consumed by respondents other than rice as staple food quite varied. The largest percentage of respondents' food ingredients choices were: the combination of tubers and bananas (21.05\%); the combination of sago, corn, tubers, and bananas (12.78\%); the combination of tubers, bananas, and corn $(10.53 \%)$; as well as corn in various forms of processing, but mostly in the form of corn rice (around 8.27\%).

The intensity of respondents' consumed food ingredients other than rice was also quite diverse. Generally, they stated that they often (more than 4 times a month) consumed these ingredients, some even every day, but there were also those who said they were uncertain for some time. Whether rice could be replaced with other types of food was answered differently by respondents: agree- $4.55 \%$, disagree- $28.79 \%$, and sometimes need- $66.67 \%$. Respondents' perceptions about whether rice as a staple food needed to be replaced with other food ingredients were quite diverse, but generally indicated that rice as the staple food needed to be replaced only occasionally with other foods.

Regarding the ability of respondents to replace rice with other food ingredients, many did not seem to have an opportunity for other commodities to replace rice as the staple food; the results of the survey show: capable- $26.32 \%$, unable- $16.54 \%$, no answer- $5.26 \%$, and not yet able to$51.88 \%$. This shows that most respondents were not able to replace rice as the staple food.

Even though the respondents were not able yet to replace their staple food, food diversification has begun to occur. This implies that the acceleration program of food consumption diversification, especially those related to the diversity of the community's food consumption has been achieved. This result is in accordance with the findings of Alam [10] in Lempake village, where the community has seen a substitute crop for the main staple of rice, such as various types 
of tubers, corn, soybeans, and cassava. Food diversification was a solution that considered very good for solving problems in meeting food needs $[11,12]$. By structuring a food pattern that was not only dependent on one food source, it was possible for the community to determine their own choice of food, so could generate household food security $[13,14]$. If household food security could be achieved, then national food security would also increase. Food consumption diversification could also increase household nutrition fulfillment $[15,16]$.

\section{CONCLUSION}

More than $70 \%$ of the respondents had arable land area above 1.0 ha, with quite a high variety of cultivated crops type, ranging from food crops, horticulture to plantation crops. The average area of yardland was $1,384.5 \mathrm{~m}^{2}$, which was a potential resource if it could be utilized maximally. The types of crops cultivated in yardland quite varied between food, fruit, vegetables and medicinal plants. However, most of them were vegetable crops, while there was very little diversification effort with fish (ponds) and livestock. The fulfillment of household consumption from farming was generally still below $50 \%$ of total consumption. Food ingredients that were usually consumed other than rice were corn, tubers, and bananas, with a fairly frequent consumption intensity (above 4 times a month), which meant that they had the potential to increase consumption of non-rice foods. The types of food that were considered suitable to replace rice were tubers and corn. Most households felt that they were unable yet to replace rice as the staple food.

\section{REFERENCES}

[1] Choudhury, S. and Headey, D. 2017. What drives diversification of national food supplies? A cross-country analysis. Global Food Securit, 15, 85-93.

[2] Dwivedi, S.L., van Bueren, E.T.L., Ceccarelli, S., Grando, S., Upadhyaya, H.D. and Ortiz, R. 2017. Diversifying Food Systems in the Pursuit of Sustainable Food Production and Healthy Diets. Trends in Plant Science, 22(10), 842-856.

[3] Mulwa, C.K. and Visser, M. 2020. Farm diversification as an adaptation strategy to climatic shocks and implications for food security in northern Namibia. World Development, 129, 104906.

[4] Rahman, H.P.S and M. Ariani, 2008. Penganekaragaman Konsumsi Pangan Di Indonesia : Permasalahan dan Implikasi Untuk Kebijakan dan Program. Analisis Kebijakan Pertanian, Vol. 6 (2) : 140-154.

[5] Badan Ketahanan Pangan, 2009. Peraturan Presiden Nomor 22 Tahun 2009, Tentang Percepatan Penganekaragaman Pangan Nasional. Kementerian Pertanian R.I., Jakarta.

[6] BKPD Sulawesi Tengah, (2010). Bahan Sosialisasi Peraturan Gubernur Sulawesi Tengah Nomor 15 Tahun 2010. Badan Ketahanan Pangan Daerah Provinsi Sulawesi Tengah, Palu.

[7] Tri Wahono, (1997). Peran Makanan Tradisional Dalam Mewujudkan Pola Pangan Harapan. Habitat, Vol. 9, No. 101 : 59-65.

[8] Badan Ketahanan Pangan, 2013. Pedoman Pelaksanaan Gerakan Program Percepatan Penganekaragaman Pangan Konsumsi Pangan (P2KP) Tahun 2013. Pusat Penganekaragaman Konsumsi Pangan, Badan Ketahanan Pangan, Kementerian Pertanian R.I., Jakarta. 
[9] Badan Ketahanan Pangan. 2019. Direktori perkembangan konsumsi pangan. Badan Ketahanan Pangan Kementerian Pertanian Indonesia.

[10] Alam, A.S. 2019. Implementasi program percepatan penganekaragaman konsumsi pangan (p2kp) pada kelompok wanita tani di Kelurahan Lempake Kecamatan Samarinda Utara. Jurnal Administrative Reform, 7(1): 1-7.

[11] Utami, A.W., Cramer, L.A. and Nancy Rosenberger, N. 2018. Staple Food Diversification Versus Raskin: Developing Climate Change Resilience in Rural Indonesia. Human Organization, 77(4), 359-370.

[12] Etea, B.G., Zhou, D., Abebe, A.A. and Sedebo, D.A. 2019. Household Income Diversification and Food Security: Evidence from Rural and Semi-Urban Areas in Ethiopia. Sustainability, 11, 1-16.

[13] Anderzén, J., Luna, A.G., Luna-González, D.V., Merrill, S.C., Caswell, M.,V. Méndez, E., Jonapá, R.H. and Cacho, M.M.T.G. 2020. Effects of on-farm diversification strategies on smallholder coffee farmer food security and income sufficiency in Chiapas, Mexico. Journal of Rural Studies, 77, 33-46.

[14] Nantanga, K.K.M. and Amakali, T. 2020. Diversification of mopane caterpillars (Gonimbrasia belina) edible forms for improved livelihoods and food security. Journal of Arid Environments, 177, 104148

[15] Murendo, C., Gwara, S., Mazvimavi, K. and Arensen, J.S. 2019. Linking crop and livestock diversification to household nutrition: Evidence from Guruve and Mt Darwin districts, Zimbabwe. World Development Perspectives, 14, 100104.

[16] Birthal, P.S., Hazrana, J. and Negi, D.S. 2020. Diversification in Indian agriculture towards high value crops: Multilevel determinants and policy implications. Land Use Policy, 91, 104427. 